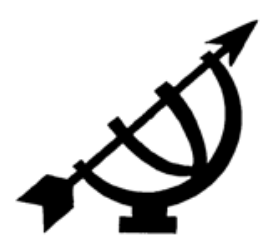

\title{
'n Vergelyking van Calvyn se 1545- Kategismus en die Heidelbergse Kategismus oor die Onse Vadergebed
}

\author{
C.F.C. Coetzee, \\ Skool vir Dogmatologie \\ Potchefstroomkampus \\ Noordwes-Universiteit \\ POTCHEFSTROOM \\ E-pos: callie.coetzee@nwu.ac.za
}

Det Dominus nobis in caelestis suae sapientiae mysteriis cum vero pietatis profectu versari in gloriam suam et aedificationem nostram. Amen.

Mag die Here ons dit gun om ons met waaragtige vordering in godsvrug met die geheimenisse van sy hemelse wysheid besig te hou tot sy heerlikheid en tot ons opbou. Amen.

(Die gebed waarmee Calvyn elke lesing ingelei het; vgl. Simpson, 1981:24.)

Believe me, my Lord, the Church of God will never preserve itself without a Catechism.

(Uit 'n brief van Calvyn aan Somerset, 22 Oktober 1548;

vgl. Wallace, 1990:97.)

\section{Abstract}

\section{A comparison between Calvin's Catechism of 1545 and the Heidelberg Catechism on their exposition of the Lord's Prayer}

Several studies on the relationship between Calvin's Catechism (1545) and the Heidelberg Catechism have already been conducted. However, the need for a study of a comparison between the two catechisms on the Lord's Prayer was emphasised at the South African Calvin Research Conference in 2004. In the sixteenth century Reformation the Lord's Prayer was a subject of considerable importance. Calvin wrote no less than eight different expositions of the Lord's Prayer in his commentaries, catechisms of 1538 and 1545 and the different editions of his "Institutes". In both the Geneva Catechism of 1542/1545 and the Heidelberg Catechism the exposition of the 
Lord's Prayer forms an important part. A comparison of these expositions leads to the conclusion that the theological insights of John Calvin played a major role in the formulation of the Heidelberg Catechism. The Heidelberg Catechism is part of our Calvinist heritage and should still be used in the instruction of our children and confessed as our true and living faith.

\section{Opsomming}

\section{'n Vergelyking van Calvyn se 1545-Kategismus en die Heidelbergse Kategismus oor die Onse Vadergebed}

Daar het reeds 'n hele aantal studies oor die verhouding tussen Calvyn se Kategismus (1545) en die Heidelbergse Kategismus die lig gesien. Die behoefte aan 'n vergelyking tussen hierdie Kategismus en die Heidelbergse Kategismus wat die verklaring van die Onse Vadergebed betref, is reeds by die SuidAfrikaanse Calvynnavorsingskongres in 2004 uitgespreek. In die sestiende-eeuse Reformasie het die verklaring van die Onse Vadergebed 'n baie belangrike plek ingeneem. Uit die pen van Calvyn het daar agt verklarings verskyn in sy kommentare, kategismusse van 1538, 1545 en die verskillende uitgawes van die "Institusie". In sowel die Geneefse Kategismus van 1542/1545 as die Heidelbergse Kategismus vorm die verklaring van die Onse Vadergebed 'n belangrike deel. 'n Vergelyking van hierdie verklarings, toon aan dat die teologiese insigte van Calvyn 'n belangrike rol gespeel het in die formulering van die Heidelberger. Die Heidelbergse Kategismus is deel van ons Calvinistiese erfenis en steeds die lewende belydenis van die ware geloof van baie kerkgemeenskappe en behoort steeds gebruik te word in die kategetiese onderrig.

\section{Inleiding}

Tydens die Sewende Suid-Afrikaanse Calvynnavorsingskongres te Stellenbosch, maak prof. Neuser aan die einde van sy voordrag oor Calvyn se verklaring van die Onse Vadergebed die volgende opmerking: "It would ... be of value to make a detailed comparison of the interpretations of the Lord's Prayer in the catechism of Heidelberg and that of John Calvin" (Neuser, 2008:107).

Alhoewel die Kategismus van Calvyn minder bekend is as sy Magnum Opus, die "Institusie van die Christelike godsdiens" en ook minder bekend as die Heidelbergse Kategismus, is dit ' $n$ invloedryke en baie belangrike belydenis. Trouens, volgens Wright (2004:284), was dit in Genève nie die Institusie nie, maar die Kategismus "that served as the official statement of Genevan church doctrine for most of Calvin's life". Die Engelse vertaling van die Kategismus het selfs 
'n prominente rol in die Skotse reformasie gespeel (Wright, 2004: 284).

'n Ander uitnemende Calvynkenner, L.F. Schulze, handel indringend oor die moontlike invloed wat die Geneefse Kategismus van 1542/ $1545^{1}$ kon gehad het op die Heidelbergse Kategismus van 1563 (vgl. Schulze, 1993).

Die keuse van die onderwerp vir hierdie artikel moet teen bogenoemde agtergrond gesien word.

Die voorlopige navorsing wat wel gedoen is, stel die navorser ook voor bepaalde probleme. 'n Literatuursoektog bevestig die opmerking van Neuser, naamlik dat daar behoefte bestaan aan 'n vergelyking tussen Calvyn se Kategismus en die Heidelbergse Kategismus oor die Onse Vadergebed. Geen literatuur oor die spesifieke onderwerp kon in die literatuursoektog opgespoor word nie. 'n Verdere probleem is dat daar nie ' $n$ indringende verklaring bestaan oor die Kategismus van 1542/1545 nie (behalwe moontlik die verklaring deur Calvyn self van klein gedeeltes van die Kategismus waarna Neuser, 2008:96 verwys), soos wel die geval is met die Heidelbergse Kategismus en ook met die eerste Kategismus van Calvyn (1538). In laasgenoemde geval word na die magistrale werk van Hesselink (1997) verwys. Die voortgaande Calvynnavorsing sal ongetwyfeld baat vind by 'n soortgelyke kommentaar oor die 1542/ 1545-kategismus. Wat die Heidelbergse Kategismus betref, bestaan daar 'n onnoembare aantal kommentare en sien steeds nuwe publikasies die lig. ' $n$ Derde probleem is dat die Heidelbergse Kategismus, ten spyte van al die kategismusse van die sestiende eeu wat tot beskikking van die opstellers was, insluitend dié van Genève, tog 'n unieke en oorspronklike karakter vertoon, sodat dit nie altyd moontlik is om direkte invloede aan te toon nie (vgl. Schulze, 1993:495).

Teen hierdie agtergrond word gepoog om enkele lyne te trek vir 'n vergelyking tussen die Kategismus van 1542/1545 en die Heidelbergse Kategismus. 2

1 Die Kategismus het die eerste keer in 1542 in Frans verskyn en 'n Latynse vertaling is in 1545 uitgegee (vgl. De Greef, 2004:50). Calvyn voer ten minste vier redes aan waarom hy sy Kategismus ook in Latyn gekryf het, ten spyte van teenstand uit verskeie oorde (vgl. Simpson, 1981:39).

$2 \quad$ Wat die Kategismus van Calvyn betref, word dankbaar gebruik gemaak van die Afrikaanse vertaling deur H.W. Simpson (1981). Simpson was ook verantwoor- 


\section{Die Kategismus van Calvyn en die Heidelbergse Kategismus}

Calvynnavorsers stem oor die algemeen saam dat die Heidelbergse Kategismus duidelike invloed vertoon van die Kategismus van die kerk van Genève, 1542/1545 (Le Catechisme de l'eglise de Geneve, 1542, Catechismus ecclesiae Genevensis, 1545), alhoewel daar nuanseverskille bestaan oor presies hoe ver hierdie invloed strek. Klooster (1972:181-182) bestempel die Heidelbergse Kategismus as "a distinctly Calvinistic catechism". "Heidelberg was greatly influenced by Geneva." (Klooster, 1972:192.) De Greef (2004:50) noem die Geneefse Kategismus "the forerunner of the Heidelberg Catechism". Wendel (1963:80) verwys na die talle vertalings van die Geneefse Kategismus wat die lig gesien het en noem dit die "basis for the Catechism of Heidelberg". Simpson (1981:26) is oortuig dat daar weinig twyfel bestaan dat sowel Olevianus as Ursinus, die twee hoofopstellers van die Heidelbergse Kategismus, "'n sterk klap weg gehad het" van Calvyn se Kategismus en dat hierdie invloed positief neerslag gevind het by die skepping van die Heidelberger. Calvyn se Kategismus was een van die belangrikste bronne by die opstel van die Kategismus van Heidelberg (Simpson, 1981:38). In 'n ander publikasie (Calvyn, 1981: Voorwoord) herhaal Simpson sy standpunt dat die bydrae van Calvyn se Kategismus tot die vorming van die Heidelbergse Kategismus sonder meer duidelik is. In dieselfde asem verklaar hy egter: "Die verskille tussen Calvyn se Kategismus en ons eie Heidelberger van Olevianus en Ursinus is in die ooglopend". Laasgenoemde stelling verwys waarskynlik na die formele of strukturele verskille waarop daar later teruggekom word.

Verboom wat 'n diepgaande studie oor die teologie van die Heidelbergse Kategismus die lig laat sien het, wys ook op die invloed van Calvyn se Kategismus, saam met ander kategismusse uit die sestiende eeu (die twee catechismi van Leo Judae en die Groot Kategismus van J. a Lasco) op die Heidelbergse Kategismus (Verboom, 1996:17). Behalwe die invloed van Calvyn, meen hy egter dat die invloed van Melanchthon en Bullinger ook duidelik in die Heidelberger aangetoon kan word (Verboom, 1996:24). Schulze (1993: 487-488) wys ook op die feit dat die opstellers van die Heidelbergse

delik vir die vertaling in Afrikaans van die 1536-uitgawe van die Institusie (Calvin, 1980) sowel as die Afrikaanse vertaling van die 1559-uitgawe (Calvyn, 1988) van die Institusie, laasgenoemde met medewerking van L.F. Schulze en C.M.M. Brink. Die Afrikaanse vertaling van die 1559-uitgawe beleef DV in 2010 'n volgende druk. 
Kategismus, die twee Zurichse kategismusse van Leo Judae, die kategismusse van Bullinger en Calvyn en andere tot hulle beskikking gehad het. Hy vestig egter ook die aandag op 'n ander aspek, naamlik dat formulerings in die kategismusse van die sestiende eeu in die meeste gevalle insigte na vore bring wat eie aan die hele Reformasie was (Schulze, 1993:488). Die Reformasie as geheel vertoon 'n onmiskenbare "homogeniteit" van die leer (Schulze, 1991:4). Die belangrikheid van Calvyn kom daarby in dat hy as die "samevatter van die insigte en leer van die Reformasie" gesien kan word (Schulze, 1991:4).

Schulze wys verder ook op die spesifieke werkswyse wat gevolg is met die opstel van die Heidelbergse Kategismus. Frederick III het as Keurvors hierin die inisiatief geneem, deurdat hy aan Ursinus opdrag gegee het om twee ontwerpe voor te lê (Schulze, 1993:488489). Die konsep van Ursinus is waarskynlik aan die einde van 1562 in die vergadering van die kerkraad en professore van die fakulteit teologie bespreek. In Januarie 1563 het die bespreking deur die superintendente en belangrikste dienaars van die kerk gevolg. In hierdie kring sou Olevianus as superintendent 'n belangrike rol kon speel en invloed op die finale teks uitgeoefen het. Op 18 Januarie 1563 word die Heidelbergse Kategismus goedgekeur en onderteken. Kort daarna verskyn dit in druk by Johannes Mayer te Heidelberg (Verboom, 1996:17). 3

Die twee persone wat 'n sleutelrol gespeel het by die opstel van die Heidelbergse Kategismus, naamlik Ursinus en Olevianus, was albei oortuigde Calviniste. Ursinus was wel ook sewe jaar lank 'n student en 'n besondere vriend van Melanchthon (Schulze, 1993:488; Klooster, 1972:193). Dit was egter juis op aanbeveling van Melanchthon dat hy in 1557 op 'n reis na Heidelberg, Straatsburg, Basel en Genève, kennis gemaak het met Calvyn, Bucer en Bullinger (Ursinus, 1886:iii). Calvyn het vir hom eksemplare van sy werke as geskenk gegee (Ursinus, 1886:iii; Klooster, 1972:193).

Volgens Proozdij (Ursinus, 1886:v) was Olevianus uit die staanspoor betrokke by die opstel van die Heidelbergse Kategismus. Olevianus meld naamlik in sy mededelings aan Bullinger dat hulle eerste ar-

3 Verboom (1996:17) wys ook daarop dat alleen veronderstel kan word dat die proses verloop het soos hy dit weergee. Daar word naamlik beweer dat die argiefstukke betreffende die totstandkoming van die Heidelbergse Kategismus na die biblioteek van die Vatikaan geneem is nadat die Paltz weer Rooms geword het. 
beid was om navorsing te doen in die veld van kategetiese literatuur. Hier het hulle veral aandag gegee aan die Kategismus van Calvyn en dié van a Lasco. Proozdij (Ursinus, 1886:v) is dus van oordeel dat Ursinus ten onregte deur sommige as die "enige vervaardiger" genoem word. "Terwijl deze soms woordelijk met Kalvijn overeenkomen, herinnert de indeeling en het praktisch gemoedelijke van genen aan den geest van Olevianus." (Ursinus, 1886:v.)

Alles in ag genome, moet waarskynlik met die konklusie van Schulze (1993:495) saamgestem word:

'n Mens sou hier nog van Calvyn se invloed kan praat maar moet tog die indirekte aard daarvan raaksien omdat sodanige insigte van Calvyn deur die 'filter' van die teologies selfstandige kommissie gegaan en deur hulle oorgeneem is omdat hulle dit as Bybels verantwoord beskou het. Immers, die Heidelbergse Kategismus is só 'n oorspronklike skepping dat daar nêrens daarin enige spoor van 'n sito-sito plagiaat gevind kan word nie.

Die ooreenkomste tussen hierdie twee belydenisskrifte moet meer as enigiets anders uit die gemeenskaplike insig in die Skrif verklaar word (Schulze, 1994:199).

\section{Calvyn en die Onse Vadergebed}

In die Reformasie van die sestiende eeu het die uiteensetting en werklike beoefening van die Onse Vadergebed 'n sentrale plek ingeneem. Talle verklarings van die modelgebed van ons Here deur Christene van verskillende taal- en belydenisagtergrond, het in dié tyd die lig gesien (McKee, 1992:88). Calvyn was ook in hierdie opsig 'n ware voorganger wat die gees van die Reformasie vergestalt het. In sy kommentaar op Psalm 50:23 bestempel hy gebed as "the chief exercise of godliness" (vgl. Hesselink, 1997:219). En in sy kommentaar op die Evangelies noem hy die Onse Vadergebed 'n uitnemende oefening in vroomheid (vgl. Neuser, 2008:98). In elkeen van die uitgawes van die Institusie neem die behandeling van die gebed in die algemeen en die verklaring van die Onse Vadergebed 'n besondere plek in. Dit geld ook vir die eerste Kategismus van 1537/1538 en die Geneefse Kategismus van 1542/1545. Sover bekend het Calvyn nie minder nie as agt verklarings van die Onse Vadergebed geskryf (Neuser, 2008:96), waarvan die uiteensetting in die Geneefse Kategismus maar een is.

Hierby moet ook in gedagte gehou word dat daar by Calvyn 'n voortgaande ontwikkeling plaasgevind het (McKee, 1992:89). Spesifiek wat die Onse Vadergebed betref, was daar by hom die strewe om 
steeds te groei in sy verstaan van die gebed (Neuser, 2008:96). Daarom is dit belangrik dat sy vroeëre verklarings met die lateres vergelyk word. Dit is egter ook belangrik om daarop te let dat Calvyn gewoonlik slegs 'n paragraaf of gedeelte in 'n latere uitgawe vervang het wanneer daar by hom meerdere teologiese insig gekom het. "I know of no example where he rewrote a paragraph entirely on stylistic grounds" (Neuser, 2008:95). Wat die Institusie betref, was dit gewoonlik sy bedoeling om uit te brei, deur sinne en paragrawe in 'n volgende uitgawe by te voeg (Neuser, 2008:95).

Vanaf sy eerste uiteensetting of verklaring van die Onse Vadergebed in die Institusie van 1536, het Calvyn onder andere die verklarings van Luther en Erasmus tot sy beskikking gehad. In die vroeë stadium van die Reformasie was Luther se verklaring die belangrikste (McKee, 1992:90) en juis ook beskikbaar in Latyn. Calvyn vind in sy verklaring egter die meeste aansluiting by die standpunt van Bucer, terwyl hulle albei die interpretasie van Chrysostomus in sy preke op Matteus aanvaar (McKee, 1992:90). McKee (1992:90-91) wys egter tereg daarop dat Calvyn se selfstandige oordeel en standpunt baie duidelik na vore kom, soos dit onder andere blyk uit sy kritiek op Erasmus.

In Calvyn se eerste Kategismus van 1537 vind ons 'n kort uiteensetting van die Onse Vadergebed wat in wese 'n vertaling is van gedeeltes van die Institusie van 1536 (McKee, 1992:91). Die Geneefse Kategismus van 1542/1545 is opmerklik uitgebrei, maar voeg baie min by ten opsigte van die inhoud van die Onse Vadergebed teenoor die Institusie van 1539 (vgl. McKee, 1992:92). Dit is egter belangrik om daarop te let dat heelparty van die veranderings in die 1539-Institusie teenoor die 1536-Institusie bestaan uit beoordeling van opponerende standpunte (McKee, 1992:91) - sake wat nie noodwendig primêr in 'n kategismus tuishoort nie.

Calvyn se verklaring van die Onse Vadergebed vorm deurgaans deel van 'n groter geheel waarin hy die breë onderwerp van gebed in die algemeen behandel, as die belangrikste oefening in die godsdiens (vgl. ook Hesselink, 1997:130, 219, wat hier 'n ooreenkoms sien met die Heidelbergse Kategismus, vr./antw. 116 wat die gebed as die vernaamste deel van die dankbaarheid bestempel). Hierin sluit hy ook aan by die Matteusevangelie, "the dominant voice in the synoptics in the sixteenth century", waar Jesus sy dissipels eers leer hoe om te bid voordat Hy aan hulle die Onse Vadergebed leer (McKee, 1992:93). 


\section{4. 'n Vergelyking tussen die 1542/1545-Kategismus van Calvyn en die Heidelbergse Kategismus (1563)}

\subsection{Formeel/struktureel}

'n Vergelyking van die Geneefse Kategismus met die Heidelbergse Kategismus bring in die eerste plek, wat formele of strukturele aspekte betref, die volgende aan die lig: 4

- In die Geneefse Kategismus omvat die gedeelte wat handel oor die gebed, insluitende die Onse Vadergebed, 62 vrae en antwoorde, terwyl dieselfde gedeelte in die Heidelbergse Kategismus slegs dertien vrae en antwoorde bevat. Hierop kom ons later terug.

- Die Geneefse Kategismus bevat 21 vrae en antwoorde oor die gebed in die algemeen voordat dit by die behandeling van die Onse Vadergebed kom. In die Heidelbergse Kategismus is daar slegs twee (of hoogstens drie, indien vraag en antwoord 118 ook hierby gereken word) vrae en antwoorde oor gebed as sodanig, voordat die behandeling van die Onse Vadergebed aan die orde kom.

- In die Heidelbergse Kategismus vorm die gedeelte oor die gebed tegelyk ook die slotgedeelte van die Kategismus as geheel. In die Kategismus van Calvyn volg daar ná die gedeelte oor die gebed nog 77 vrae en antwoorde oor die Woord en sakramente.

- In die Kategismus van 1542/1545 is daar nie 'n aparte vraag en antwoord oor die woord amen nie. Ook in die eerste Kategismus kom dit nie aan die orde nie (vgl. Hesselink, 1997:33), alhoewel Calvyn in sy ander verklarings wel daaroor handel (vgl. onder andere Calvyn, 1980:208; 1988:1152; Inst. 3.20.47). In die Hei-

$4 \quad$ Wat die Heidelbergse Kategismus in die geheel betref, kom Schulze (1994:203) tot die konklusie dat die invloed van Calvyn ook meegewerk het "om die struktuur van die Heidelberger te stempel". Schulze trek die konklusie veral na aanleiding van die Heidelberger se navolging van Calvyn in sy leer oor die drievoudige amp van Christus en die sogenaamde derde gebruik van die wet. Wat die struktuur van die Heidelbergse Kategismus betref, maak Schulze (1994:208) wel die stelling dat die Heidelberger struktureel tot dieselfde tipe as die Geneefse Kategismus behoort, maar hy toon ook aan dat die warmte van toon en die persoonlike aard van die antwoorde meer aan Luther se Klein Kategismus herinner as aan dié van Calvyn, terwyl die formulering van die vrae korter is as dié van Calvyn en die betoog bondiger en eenvoudiger (Schulze, 1994:209). 
delbergse Kategismus handel die heel laaste vraag en antwoord oor die betekenis van amen. Ons kom ook hierop later terug.

- Bucer en Calvyn, soos Chrysostomus, onderskei ses bedes in die Onse Vadergebed. Hierin verskil hulle van Augustinus, wie se standpunt ook deur Luther en andere in die sestiende eeu gehuldig is (McKee, 1992:94). Volgens hulle moet daar sewe bedes onderskei word. Die Geneefse Kategismus handhaaf die indeling in ses bedes en die opstellers van die Heidelbergse Kategismus volg Calvyn hierin na, alhoewel die Heidelbergse Kategismus nie, soos die Geneefse Kategismus in vrae 258 tot 260 spesifieke aandag aan die indeling gee nie. Die invloed van Calvyn is dus ook hier onmiskenbaar (vgl. Verboom, 1996:311).

\subsection{Inhoudelik}

Wat die inhoudelike betref, is 'n vergelyking tussen die Geneefse Kategismus (GK) en die Heidelbergse Kategismus (HK) moeiliker, onder andere in die lig van wat hierbo gesê is oor die gemeengoed van die Reformasie, die groot aantal kategismusse wat deur die opstellers van die Heidelbegse Kategismus gebruik kon word en die selfstandigheid van Calvyn sowel as die opstellers van die Heidelberger.

Tog is daar 'n hele aantal opmerklike ooreenkomste, sowel as verskille waarop kortliks die aandag gevestig kan word.

\subsubsection{Die aanhef van die Onse Vadergebed}

Sowel die Geneefse Kategismus as die Heidelbergse Kategismus begin met die vraag waarom God as Vader aangeroep moet word (GK L/S 261, HK vr./antw. 120). Albei kategismusse beklemtoon in die antwoord die kinderlike vertroue op God, wat alleen ter wille van Christus ons Vader geword het en dat hierdie kinderlike vertroue die noodsaaklike grond vir ' $n$ ware gebed is. Die onderskeid tussen aardse vaders en God as ons Vader word ook deur albei beklemtoon. In die 1559-uitgawe van die Institusie (Calvyn, 1988; Inst. 3.20.37) het Calvyn ook 'n verwysing na die Heilige Gees bygevoeg deur Wie ons roep "Abba", "Vader".

Die kategismusse verskil op dié punt dat die Geneefse Kategismus in 'n aparte vraag (264) ingaan op die feit dat God aangespreek word as "ons" Vader, "eerder as in besonder 'jou Vader"'. Die Heidelbergse Kategismus gee nie in die besonder aandag aan hierdie saak nie. 
Ook oor die byvoeging "wat in die hemele is", is daar opmerklike ooreenstemming. Calvyn (1981; GK 265, 266) wys op die verhewenheid en almag van God en dat die byvoeging ons verhoed om van God "iets vleesliks of wêrelds" te bedink. Ook dra dit daartoe by om ons vertroue op God weer aan te wakker. Die Heidelberger (vr./ antw. 121) beklemtoon dat ons van die "hemelse majesteit van God nie aards moet dink nie" en van sy Almag alles moet verwag.

\subsubsection{Die eerste bede}

Ook wat die eerste bede betref, is daar saaklik ooreenstemming deurdat albei kategismusse die aspek van die kennis van God beklemtoon. Albei verwys ook eksplisiet na die werke van God.

Calvyn vestig telkens (GK 267 en 268) die aandag daarop dat die verheerliking van God onder alle mense bevorder en geopenbaar sal word. Ook hier gaan dit vir Calvyn dus om die regte wyse om God te eer en te aanbid - die een saak wat deur Zachman (2006: 141) bestempel word as "a unifying theme" wat al vier dele van die Geneefse Kategismus saambind. In die Heidelbergse Kategismus (vr./antw. 122) word die verheerliking van God onder alle mense wel ook geïmpliseer, veral in die sinsnede dat God se Naam "nie om ons ontwil gelaster nie maar geëer en geprys word".

\subsubsection{Die tweede bede}

Ook wat die tweede bede betref, vind ons 'n baie treffende ooreenstemming. Alhoewel Calvyn sê dat hierdie bede uit twee dele bestaan, naamlik dat God "die uitverkorenes deur sy Gees regeer en verwerptes ... vernietig" (GK 269), beklemtoon hy tog ook die aspek van die bewaring en vermeerdering van die kerk (GK 270) wat in die Heidelbergse Kategismus ook aan die orde kom. McKee (1992:98) wys verder daarop dat Calvyn se meer institusionele verwysing na die kerk ook in sy latere verklaring van die tweede bede na vore kom, deurdat hy in die 1559-Institusie praat van die kerk in plaas van die gelowiges. In albei kategismusse word die Skrifwaarheid gestel dat God se Koninkryk reeds daar is en dat die tweede bede gebid word "totdat" die volkomenheid van die ryk kom. Sowel die Geneefse Kategismus as die Heidelbergse Kategismus sluit die verklaring van hierdie bede af met ' $n$ woordelikse aanhaling van 1 Korintiërs 15:28. In die Heidelbergse Kategismus word twee maal eksplisiet verwys na die regering van God deur sy Woord, terwyl die Geneefse Kategismus dit nie pertinent noem nie. In die 1536Institusie verwys Calvyn egter spesifiek na God se heilige Woord wat "soos 'n septer na bo gerig is" (Calvyn, 1980:194). Ook in sy 
kommentaar op die Evangelies word die kombinasie van Woord en Gees beklemtoon (vgl. McKee, 1992:99), sodat gekonstateer kan word dat daar ook in hierdie opsig volkome ooreenstemming is tussen die Heidelbergse Kategismus en die gedagtes van Calvyn.

Dit is wel opmerklik dat die toon van die Heidelbergse Kategismus baie meer persoonlik is en ook dat die verklaring in die vorm van 'n gebed geformuleer is. Die Kategismus van Calvyn daarteenoor is meer saaklik en objektief. Hierdie verskil geld deurgaans wat die verklaring van die Onse Vadergebed betref.

\subsubsection{Die derde bede}

Die duidelikste ooreenkoms tussen die Geneefse en Heidelbergse Kategismus, wat die formulering ten opsigte van die derde bede betref, kom na vore in die verwysing na "alle mense" wat deur hierdie bede ingesluit word. Dit is wel opmerklik dat Calvyn in die 1536-uitgawe van die Institusie nie die tweede deel van die derde bede verklaar nie, terwyl daar in die eerste kategismus slegs 'n baie kort verwysing voorkom, naamlik "that just as he is wont to do in heaven, so on earth ..." (vgl. Hesselink, 1997:31). In die Kategismus van 1542/1545 sowel as die Heidelbergse Kategismus kom die verklaring van hierdie deel van die bede egter wel aan die orde. Die Heidelbergse Kategismus is hier miskien meer konkreet in die spesifieke verwysing na "amp en beroep". Dit is heel waarskynlik te danke aan die invloed van Melanchthon op sy leerling, Ursinus (vgl. Verboom, 1996:313).

Verboom (1996:314-315) is van mening dat dit in die Geneefse Kategismus én in die Heidelbergse Kategismus om die verborge sowel as die geopenbaarde wil van God gaan. Die outeur van hierdie artikel is van mening dat dit nie uit die formulering van albei kategismusse volkome duidelik is nie en dat die klem wel grootliks op die geopenbaarde wil van God val. In hierdie opsig verskil Calvyn sowel as die Heidelberger in elk geval van Luther, wat by die derde bede uitsluitlik aan God se verborge wil dink (vgl. Verboom, 1996: 312).

\subsubsection{Die vierde bede}

Wat die vierde bede betref, moet eerstens opgemerk word dat Calvyn hier radikaal verskil van Erasmus, vir wie dit in hierdie bede om die bonatuurlike gaan (vgl. ook McKee, 1992:100-102). Volgens Calvyn (1988; Inst. 1559, 3.20.44) stem hierdie opvatting van Erasmus "baie weinig ooreen met Christus se bedoeling". Luther het ook 
aanvanklik die "daaglikse brood", behalwe op gewone voedsel, op die prediking van die Woord en op die Nagmaal laat sien (McKee, 1992:100).

Hier is weereens sonder meer die duidelikste ooreenstemming tussen Calvyn se Kategismus en die Heidelbergse Kategismus deurdat albei die vierde bede as gebed vir ons liggaamlike of stoflike behoeftes sien in die wydste sin van die woord. Albei beklemtoon ook die feit dat ons arbeid en gawes nie uitgeskakel word nie, maar wel volkome afhanklik is van die seën van God.

Calvyn se uiteensetting word wel ook in hierdie geval daardeur gekenmerk dat dit aansienlik breedvoeriger is as die Heidelbergse Kategismus. Calvyn gaan byvoorbeeld afsonderlik in op die vraag na die betekenis van "daaglikse" en "vandag" (GK 279), asook waarom ons mag praat van "ons" brood (GK 278).

\subsubsection{Die vyfde bede}

In Calvyn se uiteensetting van die vyfde bede is die agtergrond van die Roomse dwaling van die verdienstelikheid van die goeie werke, die aflaatstelsel, die Mariaverering, ensovoorts sonder meer duidelik. In vraag 282 word byvoorbeeld gevra: "Is daar dan geen sterflike mens wat sonder hierdie genade kan klaarkom nie?" En die antwoord lui: "Volstrek niemand nie! ... Ons hoor ook wat die Skrif getuig, naamlik dat as iemand sou begeer om homself voor die aangesig van God te verontskuldig hy 'n duisendmaal skuldig sal wees". Vraag 284 stel: "Jy sê dus dat ons uit vrye barmhartigheid van God vergiffenis van ons sondes verkry?" En die antwoord lui soos volg: "Ja, want as ons selfs vir net een van ons geringste sondes vergelding moes gee, sou ons nooit daaraan kon voldoen nie". In die 1536-uitgawe van die Institusie verwys hy pertinent na die "verdienstes" en die "aflate" wat aan God opgedring word (Calvyn 1980:202). "Calvin's discussion of the fifth petition includes the strongest Protestant notes" (McKee, 1992:103).

Die Geneefse Kategismus en die Heidelbergse Kategismus stem weereens saaklik daarin ooreen dat die vergifnis van die sondes volstrek afhanklik is van God se genade in Jesus Christus.

Wat die tweede deel van die vyfde bede betref, bely ons in die Heidelbergse Kategismus: "Ons bid dit van $U$ omdat ons hierdie bewys van u genade in ons vind ..." (HK, vr./antw. 126). Die Geneefse Kategismus (286) stel dit soos volg: "Deur ... sy genade en barmhartigheid na te doen, toon ons dat ons waarlik sy kinders is." 


\subsubsection{Die sesde bede}

Hierbo is reeds daarop gewys dat Calvyn en Bucer hierdie bede as één bede sien wat uit twee dele bestaan, teenoor Augustinus, Luther en andere wat dit as twee afsonderlike bedes gesien het.

Calvyn se uiteensetting van die sesde bede is weereens aansienlik breedvoeriger as díe van die Heidelbergse Kategismus en bevat sewe vrae teenoor die één van laasgenoemde. Dit sluit onder andere 'n persoonlike vraag in (GK 293): "Wat beteken die woord 'versoeking' vir jou?", asook 'n vraag (GK 294) oor die kwessie dat versoeking meer in besonder 'n eienskap van Satan blyk te wees en nie van God nie (vgl. behalwe die GK ook die verklaring in die Institusie van 1536 - Calvyn, 1980:205).

Weereens is die saaklike ooreenstemming klinkklaar. Trouens, daar is selfs feitlik woordelikse ooreenstemming in uitdrukkings soos "onophoudelik aanval", "omdat ons uit onsself so swak is", "die krag van sy Gees" en "weerstand bied".

\subsubsection{Die slot van die gebed}

Wat die uiteensetting van die slot van die Onse Vadergebed betref, moet gekonstateer word dat die Heidelbergse Kategismus sonder twyfel 'n veel ryker verklaring gee as die Geneefse Kategismus. 'n Vergelyking van die twee formulerings bevestig hierdie stelling sonder meer:

GK 295: "Hier word ons weer vermaan dat ons gebede eerder op die mag en die goedertierenheid van God moet steun as op ons eie selfvertroue. Daarbenewens word ons geleer om ons gebede met lofbetuiging aan God af te sluit." Calvyn sluit sy behandeling van die Onse Vadergebed af met 'n vraag of dit geoorloof is om iets meer te vra as net dit wat in die Onse Vadergebed saamgevat is (GK 296).

HK antw. 128; "Ons bid dit alles van $U$ omdat $U$ as ons Koning, wat mag oor alles het, ons alle goeie dinge wil en kan gee sodat daardeur nie ons nie, maar u heilige Naam ewig geprys sal word."

Nietemin is die ooreenstemming ook hier duidelik, naamlik in die beroep op die mag van God en die afsluiting met lofprysing.

\subsubsection{Amen}

Hierbo is reeds daarop gewys dat dit opmerklik is dat Calvyn nie in die Kategismus van 1542/1545 'n verklaring gee van die woord amen nie, terwyl die Heidelbergse Kategismus op ' $n$ baie sinvolle 
wyse daarmee afsluit. Dit is inderdaad vreemd, aangesien die woord amen deel vorm van die teks in Matteus 6:13, alhoewel die tweede gedeelte van die sesde bede en die res van die Onse Vadergebed in Lukas 11 ontbreek.

Hier moet dus 'n verskil tussen die Geneefse Kategismus en die Heidelbergse Kategismus gekonstateer word.

\section{Samevattende konklusies en slotopmerkings}

Daar kan nie bo enige twyfel vasgestel word wat Calvyn se beoordeling van die Heidelbergse Kategismus was nie. Wat wel histories vasstaan, is dat Olevianus kort ná die publikasie van die Heidelberger, vroeg in 1563, 'n kopie van die Duitse uitgawe aan 'n vriend in Genève gestuur het en kort daarna ook kopieë van die Latynse vertaling na Calvyn en Beza (Klooster, 1994:311). In 'n brief aan Calvyn, gedateer 3 April 1563, meld Olevianus dat hy die kopie aan hom gestuur het (Klooster, 1994:311). Hy noem dit selfs dat hy vroeër beplan het om ' $n$ voorlopige konsep van die Heidelberger aan Calvyn te stuur, maar "strange tricks were put in the way. So difficult is it to reconcile many heads and bring them together" (Klooster 1994:319). Olevianus sluit sy brief af met die woorde: "Vale et unum verbum rescribe" (Totsiens en antwoord met een woord) (Klooster 1994:319). Daar bestaan egter geen getuienis dat Calvyn ooit direk hierop gereageer het nie.

Klooster (1994) is egter van mening dat Calvyn besonder positief oor die Heidelbergse Kategismus sou geoordeel het. Hy grond sy oortuiging op die feit dat Calvyn, slegs drie maande nadat hy die brief van Olevianus ontvang het, sy kommentaar op Jeremia aan Keurvors Frederik III opgedra het. Calvyn het dit gedoen nadat hy vier jaar tevore die 1559-Institusie aan Frederik III wou opdra, maar oorreed is om dit nie te doen nie (Klooster, 1994:316). In die voorwoord van sy kommentaar op Jeremia prys hy die Keurvors in gloeiende taal vir al sy hervormings. Dit moes volgens Klooster (1994:316) sonder twyfel ook die Heidelberger ingesluit het, waarvan Calvyn toe enkele maande reeds ' $n$ kopie in sy besit gehad het.

Uiteindelik kom Klooster (1994:331) tot die volgende konklusie:

What was Calvin's attitude toward the Heidelberg Catechism? If one is looking for a one-word response, I suggest that it was an enthusiastic, 'Hurrah!' Or, perhaps better still the suggestion of Derk Visser, commentator on the first reading of this paper: 'Imprimatur!' 
Daar kan moeilik van Klooster se konklusie verskil word. 'n Vergelyking tussen die Calvyn-Kategismus van 1542/1545 en die Heidelbergse Kategismus van 1563 oor die Onse Vadergebed, bevestig wat ook deur ander studies aangetoon is (vgl. onder andere Schulze, 1993 en 1994), naamlik dat die Geneefse Kategismus waarskynlik die grootste invloed op die Heidelbergse Kategismus gehad het, alhoewel die Heidelbergse Kategismus sy eie aksent (Schulze, 1994:205) en unieke aard (Schulze, 1993:499) behou het. Die Heidelbergse Kategismus is deur en deur 'n Calvinistiese belydenisskrif. In die kerke van die reformatoriese tradisie waar daar nog erns gemaak word met die gebondenheid aan hierdie en ander belydenisse, en dit spesifiek in die verbondsonderrig aan die orde kom, word die Skrifgebonde teologie van Calvyn sodoende lewend in die harte en lewens van die kerkvolk gehou.

Sowel die Geneefse Kategismus as die Heidelbergse Kategismus is opgestel met die uitdruklike doel om as kategetiese materiaal gebruik te word. Calvyn het juis in die periode van sy verblyf in Straatsburg tot ander insigte gekom wat die metode van onderrig aan die katkisante betref (Zachman, 1996:139). Die vorm waarin die Institusie en die Kategismus van 1538 ingeklee was, was nie daarvoor geskik nie. Calvyn het dus met opset in die 1542/1545-Kategismus die dialogiese metode van vraag en antwoord, waarskynlik in navolging van Bucer, gevolg (Zachman, 1996:139; vgl. ook Simpson, 1981: 38).

Moreover, the whole style of catechesis will move from a topical summary of doctrine to an instructional interrogation, based on a dialogical model, so that children might be able to understand and defend the faith they profess before the whole church. (Zachman, 1996:139.)

In die voorwoord en aanhef tot die 1542/1545-Kategismus stel Calvyn duidelik sy erns wat die verbondsonderrig van die kinders betref en die rol wat die kategismus daarin speel:

In die kerk is daar altyd daarop ag geslaan en daar is ook noulettend daarvoor gesorg dat kinders behoorlik in die Christelike leer onderwys word ... Die werk wat ons nou bekendstel, is niks anders as die gebruik van dit wat eenmaal deur Christene en opregte aanbidders van God waargeneem is nie. Dit het nooit verlore gegaan nie, behalwe wanneer die kerk volkome bedorwe was. (Calvyn, 1981:5.)

Ook: 
... die eensgesindheid in die leer wat die kerke onderling het, kan nie met 'n duideliker bewys waargeneem word as in die Kategismus nie (Calvyn, 1981:2).

Mag alle kerke van gereformeerde belydenis en alle verbondsouers, die waarheid en aktualiteit van hierdie woorde van Calvyn steeds, ook nou met die herdenking van sy geboortejaar vyfhonderd jaar gelede, besef en toepas. Met die oog op die vervulling van ons roeping ten opsigte van ons verbondskinders en die toekoms van die kerk, besit ons nie alleen die Geneefse Kategismus van Calvyn nie, maar veral die Heidelbergse Kategismus. Ook laasgenoemde volg die uitnemende metode van vraag en antwoord.

'n Vergelyking tussen hierdie twee kategismusse in hierdie verband lei tot die konklusie dat die Heidelbergse Kategismus vir die konteks van ons tyd, selfs beter geskik is vir die kategetiese onderrig. "Die formulering van die vrae is korter as díe van Calvyn en die betoog bondiger en eenvoudiger" (Schulze, 1994:209). In die Heidelbergse Kategismus het ons die rype vrug van die sestiende-eeuse Reformasie, met Calvyn as die sleutelfiguur. Dit is 'n unieke, kosbare belydenisskrif wat steeds die lewende geloof van Skrifgetroue gelowiges verwoord. Mag die Gees dit gebruik sodat die kerk van Christus steeds ware belyers en ware bidders sal wees.

\section{Geraadpleegde bronne}

CALVIN, J. 1980 [1536]. Institusie van die Christelike godsdiens. Vertaal deur H.W. Simpson. Potchefstroom: Calvyn Jubileumboekefonds.

CALVIN, J. 1981. Calvyn se Kategismus. In Afrikaans vertaal deur H.W. Simpson. Potchefstroom: Potchefstroomse Teologiese Publikasies.

CALVIN, J. 1988. Institusie van die Christelike godsdiens. Band 3. Vertaal deur H.W. Simpson met medewerking van C.M.M. Brink. Potchefstroom: Calvyn Jubileumboekefonds.

DE GREEF, W. 2004. Calvin's writings. (In McKim, D.K., ed. The Cambridge companion to John Calvin. Cambridge: Cambridge University Press. p. 4157.)

HESSELINK, I.J. 1997. Calvin's first Catechism: a commentary. Louisville: Westminster John Knox.

KLOOSTER, F.H. 1972. Missions: the Heidelberg Catechism and Calvin. Calvin theological journal, 7(2):181-208.

KLOOSTER, F.H. 1994. Calvin's attitude to the Heidelberg catechism. (In Graham, W.F., ed. Later Calvinism: international perspectives. Kirksville: Sixteenth Century Journal Publishers. p. 311-331.)

McKEE, E.A. 1992. John Calvin's teaching on the Lord's prayer. The Princeton seminary bulletin, 2:88-106. (Supplementary issue.) 
NEUSER, W.H. 2008. Exercitium pietatis: Calvin's interpretation of the Lord's prayer. (In D'Assonville, V.E. \& Britz, R.M., eds. Prompte et sincere: bereidwillig en opreg. Seventh South African Congress on Calvin Research. Bloemfontein: UFS. p. 95-107.) (Acta Theologica Supplementum, 10.)

SCHULZE, L.F. 1991. Twee kategismusse uit die 16de eeu: 'n spieël van aksentverskuiwing. In die Skriflig, 25(1):3-27.

SCHULZE, L.F. 1993. Calvyn en die Heidelbergse Kategismus. In die Skriflig, 27(4):487-499.

SCHULZE, L.F. 1994. Die teologiese wortels en struktuur van die Heidelbergse Kategismus: 'n oorsig. Hervormde teologiese studies, 50(1-2):194-210.

SIMPSON, H.W. 1981. Calvyn: institusie, konfessie en kategismus. In die Skriflig, 59:24-41.

URSINUS, Z. 1886. Verklaring op den Heidelbergschen Catechismus: uit het Latijn door C. van Proosdij. Kampen: Zalsman.

VERBOOM, W. 1996. De theologie van de Heidelbergse Catechismus. Zoetermeer: Boekencentrum.

WALLACE, R.S. 1990. Calvin, Geneva and the Reformation. Grand Rapids: Baker.

WENDEL, F. 1965. Calvin: the origins and development of his religious thought. Trans. by P. Mairet. London: Collins. (The Fontana Library theology and philosophy.)

WRIGHT, D.F. 2004. Calvin's role in church history. (In McKim, D.K., ed. The Cambridge companion to John Calvin. Cambridge: Cambridge University Press. p. 277-288.)

ZACHMAN, R.C. 2006. John Calvin as teacher, pastor, and theologian. Grand Rapids: Baker.

\section{Kernbegrippe:}

1536-Institusie

Calvyn, Kategismus

Geneefse Kategismus

Heidelbergse Kategismus

Onse Vadergebed

\section{Key concepts:}

1536 Institutes

Calvin, Catechism

Geneva Catechism

Heidelberg Catechism

Lord's Prayer 
